\title{
HEAVY METALS DETERMINATION IN IMPORTED FROZEN MEAT
}

\author{
${ }^{I}$ Yasser M. Al-Ashmawy; ${ }^{2}$ Nader Y. Moustafa and ${ }^{2}$ Ibrahim I. Al-Hawary \\ ${ }^{1}$ B.V.Sc, Fac. of Vet. Med., Kafrelsheikh Univ, Egypt. \\ ${ }^{2}$ Food Control Dep. Fac. of Vet. Med., Kafrelsheikh Univ, Egypt.
}

\begin{abstract}
45 random samples of imported frozen meat were collected from AlGharbiah markets, Egypt. The collected samples were represented by Brazilian, Columbian and Indian meat (15 of each). The collected samples were examined for cadmium, lead and mercury concentrations on the basis of wet weight $(\mathrm{mg} / \mathrm{kg})$ by Atomic Absorption Spectrophotometer (AAS). The obtained results revealed that the mean concentrations of cadmium in the examined samples of imported frozen Brazilian, Columbian and Indian meats were $0.06 \pm$ $0.01 \mathrm{mg} / \mathrm{kg} ; 0.14 \pm 0.01 \mathrm{mg} / \mathrm{kg}$ and $0.19 \pm 0.01 \mathrm{mg} / \mathrm{kg}$, respectively, while the mean concentrations of lead in the examined samples of imported frozen Brazilian, Columbian and Indian meats were $0.35 \pm$ $0.02, \mathrm{mg} / \mathrm{kg} ; 0.41 \pm 0.02 \mathrm{mg} / \mathrm{kg}$ and $0.52 \pm 0.03 \mathrm{mg} / \mathrm{kg}$, respectively, concerning to mercury it could not be detected in the examined samples of imported frozen Brazilian meat, while the mean concentrations of mercury in the examined samples of imported frozen Columbian and Indian meats were $0.20 \pm 0.01 \mathrm{mg} / \mathrm{kg}$ and $0.37 \pm 0.02$ $\mathrm{mg} / \mathrm{kg}$, respectively. Comparing the results to the maximum permissible limits stated by the Egyptian Organization of Standardization "EOS" (2005), found that the examined imported frozen Indian meat contained the highest residual concentration of heavy metals (cadmium, lead and mercury) followed by Columbian and Brazilian.
\end{abstract}




\section{INTRODUCTION}

In order to improve the animal protein content in the Egyptian food, under the current economic situations, especially when the fresh red meat have extremely rising prices and under the limitation of the individual's income, the imported frozen meat could be replaced and must be sufficiently available with the required food content (Shafiq et al., 2009).

Imports of frozen beef in Egypt were expected to increase slightly as a result of short supply of locally produced meat coupled with a growing population (Maldonado and Sherif, 2010).

The only way to complete all the amino acids needed for our proper tissue formation, growth and repair is through the intake of animal protein. One of the most common animal protein sources in the world is the cattle meat. The cattle habitat was continually been polluted with cadmium, lead and other metals as a result of indiscriminate dumping of waste materials on the land, plants and water in which cattle was freely graze and drink (Kamala and Kumar, 1998).

Cadmium, Lead and Mercury are among the main toxic heavy metals, which accumulate in food chains and have a cumulative effect (Ferguson, 1990).

From the public health of view this work was planned to detect the concentrations of heavy metal contaminants of (Cadmium, Lead and Mercury) in imported frozen meat from different countries. 


\section{MATERIALS AND METHODS}

\section{1- Collection of samples:}

A total of 45 random samples of imported frozen meat were collected from Al-Gharbiah markets, Egypt. the collected samples were represented by Brazilian, Columbian and Indian meat (15 of each). The collected samples were examined for cadmium, lead and mercury concentrations on the basis of wet weight $(\mathrm{mg} / \mathrm{kg})$.

\section{2- Determination of heavy metal residue:}

Instrumental procedures for various analyses of heavy metals were based on those suggested in the operator manual of the Atomic Absorption Spectrophotometer "AAS" (UNICAM969AA Spectrophotometer).

\section{2-1-Digestion technique:}

The samples were prepared and digested according to the technique described by Shibamoto and Bjeldanes (1993).

\section{2-2- Preparation of blank and standard solutions:}

Preparation of blanks and standard solution in the same manner was applied for wet digestion.

\section{2-3- Analysis:}

The digest, blanks and standard solutions were aspirated by Atomic Absorption Spectrophotometer (AAS) and analyzed for cadmium, lead and mercury under the following conditions: 
Yasser M. Al-Ashmawy et., al.

\begin{tabular}{|c|c|c|c|}
\hline Conditions & Cadmium & Lead & Mercury \\
\hline Lamp wave length (nm) & 228.8 & 217.0 & 253.7 \\
\hline Lamp current (m/amp) & 10 & 15 & 10 \\
\hline Fuel flow rate & 1.2 & 1.4 & 1.2 \\
\hline Measurement time (seconds) & 4.0 & 4.0 & 4.0 \\
\hline Detection limit $(\mathrm{mg} / \mathrm{kg})$ & 0.01 & 0.01 & 0.01 \\
\hline
\end{tabular}

N.B: Estimation of heavy metals in each examined sample was expressed by $(\mathrm{mg} / \mathrm{kg})$ of wet weight samples.

\section{2-4- Quantitative determination of heavy metal residues:}

Cadmium, lead and mercury absorbency were recorded directly from the digital scale of AAS and their concentrations were calculated, according to the following equation: $\mathrm{C}=\mathrm{R} \times(\mathrm{D} / \mathrm{W})$

\section{RESULTS}

Table (1): Statistical analytical results of cadmium concentrations in the examined samples of imported frozen meat $(n=15)$.

\begin{tabular}{|c|c|c|c|c|c|}
\hline \multirow{2}{*}{$\begin{array}{c}\text { Types of } \\
\text { imported meat }\end{array}$} & \multirow{2}{*}{$\begin{array}{l}\text { NO. of positive } \\
\text { samples }\end{array}$} & \multirow{2}{*}{$\begin{array}{c}\text { Percentage of } \\
\text { positive samples }\end{array}$} & \multicolumn{3}{|c|}{ Concentrations (mg/kg) } \\
\hline & & & Min & Max & Mean \pm S.E \\
\hline Brazilian & 3 & 20.00 & 0.03 & 0.08 & $0.06 \pm 0.01$ \\
\hline Columbian & 3 & 20.00 & 0.05 & 0.31 & $0.14 \pm 0.01$ \\
\hline Indian & 5 & 33.33 & 0.06 & 0.51 & $0.19 \pm 0.01$ \\
\hline
\end{tabular}

Table (2): Acceptability of the examined imported frozen meat samples based on their concentrations of cadmium.

\begin{tabular}{|c|c|c|c|c|}
\hline Type of samples & NO. of samples & $\begin{array}{c}\text { NO. of samples } \\
\text { above MRL }\end{array}$ & $\begin{array}{l}\% \text { of samples above } \\
\text { MRL (Unaccepted) }\end{array}$ & $\begin{array}{c}\text { MRL } \\
(\mathrm{mg} / \mathrm{kg})^{*}\end{array}$ \\
\hline Brazilian & 15 & 0 & 0 & 0.1 \\
\hline Columbian & 15 & 1 & 6.67 & 0.1 \\
\hline Indian & 15 & 2 & 13.33 & 0.1 \\
\hline
\end{tabular}

* Egyptian Organization of Standardization "EOS" (2005)

$\overline{\text { Kafrelsheikh Vet. Med. J. Vol. } 10 \text { No. } 2 \text { (2012) }}$ 
Heavy Metals Determination In Imported Frozen Meat.

Table (3): Statistical analytical results of Lead concentrations in the examined samples of imported frozen meat $(n=15)$.

\begin{tabular}{|c|c|c|c|c|c|}
\hline \multirow{2}{*}{$\begin{array}{l}\text { Types of } \\
\text { imported meat }\end{array}$} & \multirow{2}{*}{$\begin{array}{l}\text { NO. of positive } \\
\text { samples }\end{array}$} & \multirow{2}{*}{$\begin{array}{c}\text { Percentage of } \\
\text { positive samples }\end{array}$} & \multicolumn{3}{|c|}{ Concentrations (mg/kg) } \\
\hline & & & Min & Max & Mean \pm S.E \\
\hline Brazilian & 3 & 20.00 & 0.17 & 0.59 & $0.35 \pm 0.02$ \\
\hline Columbian & 4 & 26.67 & 0.22 & 0.69 & $0.41 \pm 0.02$ \\
\hline Indian & 6 & 40.00 & 0.29 & 0.93 & $0.52 \pm 0.03$ \\
\hline
\end{tabular}

Table (4): Acceptability of the examined imported frozen meat samples based on their concentrations of Lead.

\begin{tabular}{|c||c||c||c||c||}
\hline Type of samples & NO. of samples & $\begin{array}{c}\text { NO. of samples } \\
\text { above MRL }\end{array}$ & $\begin{array}{c}\text { \% of samples above } \\
\text { MRL (Unaccepted) }\end{array}$ & $\begin{array}{c}\text { MRL } \\
(\mathbf{m g} / \mathbf{k g} \text { )* }\end{array}$ \\
\hline \hline Brazilian & 15 & 1 & 6.67 & 0.5 \\
\hline Columbian & 15 & 1 & 6.67 & 0.5 \\
\hline Indian & 15 & 3 & 20.00 & 0.5 \\
\hline
\end{tabular}

* Egyptian Organization of Standardization "EOS" (2005)

Table (5): Statistical analytical results of mercury concentrations in the examined samples of imported frozen meat $(n=15)$.

\begin{tabular}{|c|c|c|c|c|c|}
\hline \multirow{2}{*}{$\begin{array}{c}\text { Types of } \\
\text { imported meat }\end{array}$} & \multirow{2}{*}{$\begin{array}{l}\text { NO. of positive } \\
\text { samples }\end{array}$} & \multirow{2}{*}{$\begin{array}{c}\text { Percentage of } \\
\text { positive samples }\end{array}$} & \multicolumn{3}{|c|}{ Concentrations (mg/kg) } \\
\hline & & & Min & Max & Mean \pm S.E \\
\hline Brazilian & 0 & 0 & UD & UD & UD \\
\hline Columbian & 2 & 13.33 & 0.09 & 0.31 & $0.20 \pm 0.01$ \\
\hline Indian & 2 & 13.33 & 0.14 & 0.60 & $0.37 \pm 0.02$ \\
\hline
\end{tabular}

$\mathrm{UD}=$ Undetectable

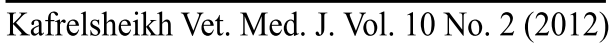




\section{DISCUTION}

It is evident from the results recorded in table (1) that the examined samples of imported frozen Brazilian, Columbian and Indian meat were positive for cadmium with concentration from 0.03 to $0.08 \mathrm{mg} / \mathrm{kg}$ with an average mean $0.06 \pm 0.01 \mathrm{mg} / \mathrm{kg} ; 0.05$ to $0.31 \mathrm{mg} / \mathrm{kg}$ with an average mean $0.14 \pm 0.01 \mathrm{mg} / \mathrm{kg}$ and 0.06 to $0.51 \mathrm{mg} / \mathrm{kg}$ with an average mean $0.19 \pm 0.01 \mathrm{mg} / \mathrm{kg}$, respectively. The above mentioned concentrations nearly similar to those obtained by Alonso et al. (2000); Korenekova et al. (2002) and Miranda et al. (2005), while higher concentrations were recorded by Irfana et al. (2004) and Nwude et al. (2011), while lower concentration was reported by Rahimi and Rokni (2008).

According to the permissible limits of cadmium stipulated by (EOS, 2005) the results in table (2) showed that $6.67 \%$ and $13.33 \%$ of the examined imported frozen Columbian and Indian meat were unacceptable, respectively.

Concerning to the results recorded in table (3) 20\%, 26.67\% and $40 \%$ of the examined samples of imported frozen Brazilian, Columbian and Indian meat were positive for lead with concentrations from 0.17 to $0.59 \mathrm{mg} / \mathrm{kg}$ with an average mean $0.35 \pm 0.02, \mathrm{mg} / \mathrm{kg} ; 0.22$ to 0.69 $\mathrm{mg} / \mathrm{kg}$ with an average mean $0.41 \pm 0.02 \mathrm{mg} / \mathrm{kg}$ and 0.29 to $0.93 \mathrm{mg} / \mathrm{kg}$ with an average mean $0.52 \pm 0.03 \mathrm{mg} / \mathrm{kg}$ for imported frozen Brazilian, Columbian and Indian meat, respectively. The above mentioned concentrations nearly similar to those obtained by Ilie et al. (2007), while higher concentrations were recorded by Korenekova et al. (2002) and Irfana et al. (2004), while lower concentration was reported by Falandysz and Lorenc-Biala (1991). 
Egyptian Organization of Standardization "EOS" (2005) stipulated a maximum permissible limit of lead to be $0.5 \mathrm{mg} / \mathrm{kg}$ in meat. So that $6.67 \%, 6.67 \%$ and $20 \%$ of the examined imported frozen Brazilian, Columbian and Indian meat was unacceptable, respectively, (Table 4).

The results recorded in table (5) showed that mercury could not be detected in the examined samples of imported frozen Brazilian meat, while $13.33 \%$ of each of examined Columbian and Indian frozen meat sample were positive for mercury with concentrations ranged from 0.09 to $0.31 \mathrm{mg} / \mathrm{kg}$ with an average mean $0.20 \pm 0.01 \mathrm{mg} / \mathrm{kg}$ and 0.14 to 0.60 $\mathrm{mg} / \mathrm{kg}$ with an average mean $0.37 \pm 0.02 \mathrm{mg} / \mathrm{kg}$, respectively. The above mentioned concentrations nearly similar to those obtained by Vos et al. (1992) and Kottferova and Korenekova(1995), while higher concentration was recorded by Irfana et al. (2004) and lower concentrations were reported by Jorhem et al. (1991) and Zarski et al. (1994).

Egyptian Organization of Standardization "EOS" (2005) not stipulated a maximum permissible limit of mercury in meat.

The obtained results in the present study indicated that the examined imported frozen Indian meat contained the highest residual levels of heavy metals (cadmium, lead and mercury) followed by Columbian and Brazilian meat.

All heavy metals are toxic at certain levels of intake, however, in contrast to elements such as lead, mercury and cadmium as far as we know play no useful role and pose a risk for both animal and human health, due to their presence in the food chain and tend to accumulate in animal tissues (Miranda et al., 2003). 


\section{REFERNCES}

- Alonso, M.L.; Benedito, L.J.; Miranda, M.; Castillo, C.; Hernandez, J. and Shore, F. R. (2000): Arsenic, cadmium, lead, copper and zinc in cattle from Galicia, NW Spain. Science Total Environ. 246(2): 237-248.

- E.O.S. "Egyptian Organization for Standardization and Quality Control" (2005): Maximum permissible limits of heavy metal in food. Detection of poisons and control, Report No.2360/93.

- Falandysz, J. and Lorenc-Biala, H. (1991): Metals in muscle tissue, liver and kidney of slaughter animals from the Northern region of Poland. Bromatol.chem Tosy kol,22(1): 19-22.

- Ferguson, J.E. (1990): The heavy elements: Chemistry, environmental impact and health effects. Pergamon Press, Oxford.

- Ilie, L.; Savu, C.; Carmen, P. and Tudor, L. (2007): Assessment of some contaminants in beef meat, major premise for food safety, Lucrari Stiinlifice Medicina Veterinara Vol. Xl, Timisoara.

- Irfana, M.; Shehla I. and Saeed, A. N. (2004): Distribution of some trace and macro minerals in Beef, International Journal of Agriculture \& Biology, 1560-8530/2004/06-5-816-820.

- Jorhem, L.; Slorach, S.; Sundstrom, B. and Ohlin, B. (1991): Lead, cadmium, arsenic and mercury in meat, liver and kidney of Swedish pigs and cattle in 1984-1988. Food Abbit Contain., 8(2):201-212. 
- Kamala, K. and Kumar, B.D. (1998): Heavy metal toxicity. Indian Pediatric. 35:209-216.

- Korenekova, B.; Skalicka, M. and Nai, P. (2002): Concentration of some heavy metals in cattle reared in the vicinity of a metallurgical industry, Vet. Arhw. 72 (5), 259-267.

- Kottferova, J. and Korenekova, B. (1995): The effect of emissions on heavy metals concentrations in cattle from the area of an industrial plant in Slovakia. Archive of environmental contamination and toxicology. 29: 400-405.

- Maldonado, J. and Sherif, S. (2010): Egypt livestock and products annual, Global Agricultural Information Network GAIN report, http://gain.fas.usda.gov.

- Miranda, M.; Lopez-Alonso, M.; Castillo, C.; Hernandez, J.; Prieto, F. and Benedito, J.L. (2003): Some toxic elements in meat from cattle slaughtered in Asturias (Northern Spain).European Food Research and Technology journal, 216, 284-289.

- Miranda, M.; Lopez-Alonso, M.; Castillo, C.; Hernandez, J. and Benedito, J. L. (2005): Effects of moderate pollution on toxic and trace metal levels in cattle from a polluted area of northern Spain. Environment International journal, 31: 543-548.

- Nwude, D. O.; Babayemi, J. O. and Abhulimen, I. O. (2011): Metal quantification in cattle at Ota Abattoir, Nigeria, Journal of Toxicology and Environmental Health Sciences Vol. 3(9), 271-274. 
- Rahimi, E. and Rokni, N. (2008): Measurement of cadmium residues in cattle slaughtered in Isfahan abattoir using grafite furnace atomic absorption spectrometry (GFAAS). Iranian Journal of Veterinary Research, Vol. 9 No. 2, 174-177.

- Shafiq, F.; Othman, A.Z. and Soleiman, N. Y. (2009): Improving the Animal Protein Level in the Egyptian Food under the Current Economic Situations Journal of Applied Sciences Research, 5(4): 415-419.

- Shibamoto, T. and Bjeldanes, L.F. (1993): Introduction to food toxicology. San Diego, California. Food science and technology journal, Academic press-XIII, 213 S. ISBN 0-12-640025-3.

- Vos, G.; Hovens, I.P.C. and Van Delft, W. (1992): Arsenic, cadmium, lead and mercury in meat livers and kidneys of cattle slaughtered in the Netherlands during 1980-1985. Food Addit. Contam., 4: 73-88.

- Zarski, T.P.; Debski, B. and Samek, M. (1994): Concentration of mercury in tissues of young beef cattle imported from Lithuania, Medycyna - Weterynaryjna, 50(2) :77-79. 
تقدير العناصر الثقيلة فى اللحوم المجمة المستورده

1 ياسر محفوظ العشماوي، 2 أ.د ـ نادر يحيى مصطفى، 2 أ.د/ إبراهيم إبراهيم الهواري

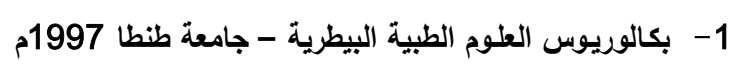

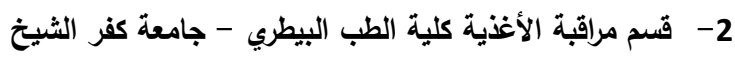

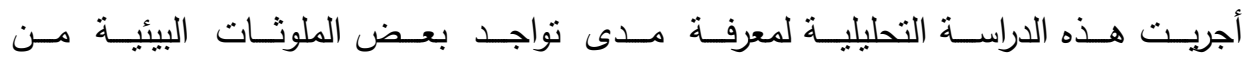

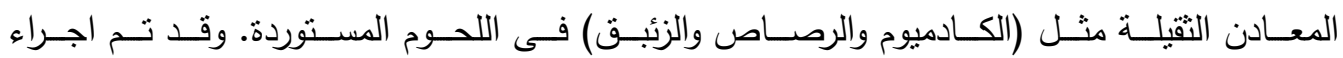

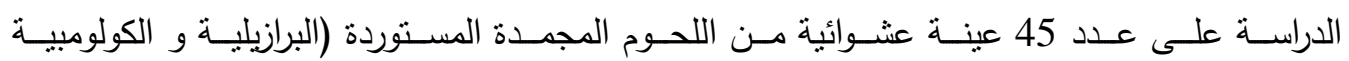
والهندية) 15 عينة من كل نوع والتي تم جمعها من مختلف الأسواق المحلية.

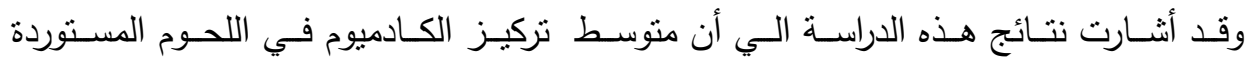

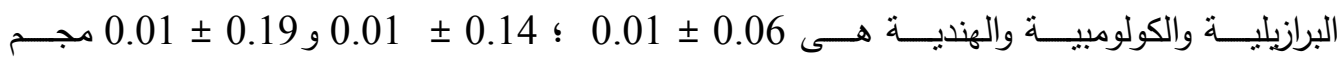

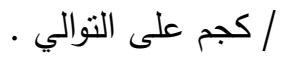

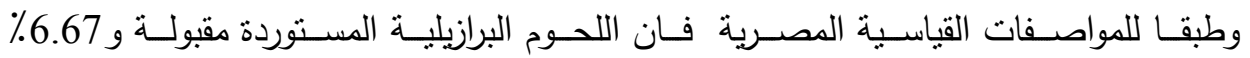

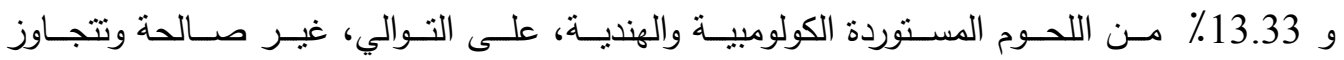
الحد الاقصى المسموح بة لعنصر الكادميوم .

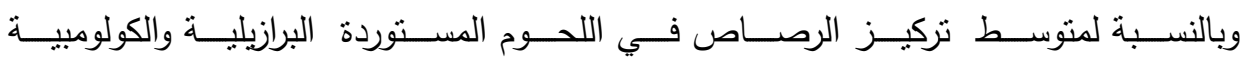

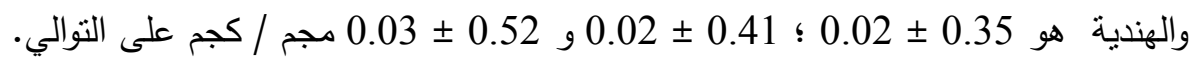

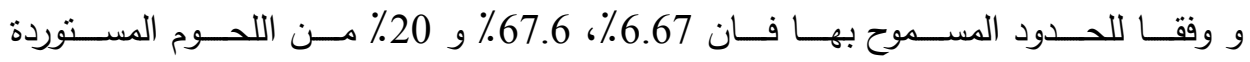

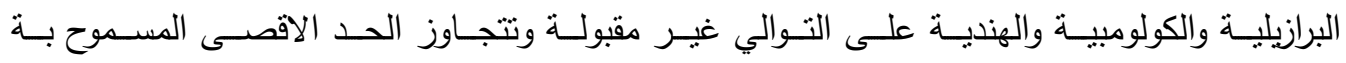

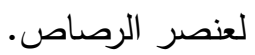

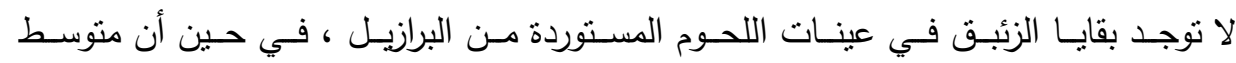

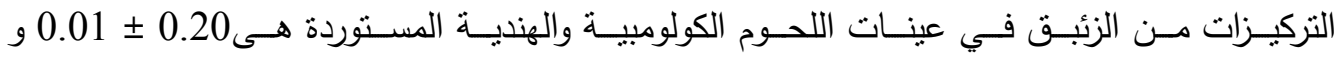
0.37 土 0.02 مجم / كجم ,على التوالي.

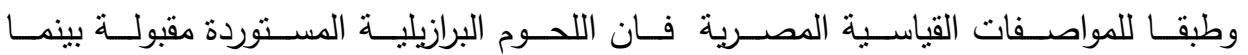

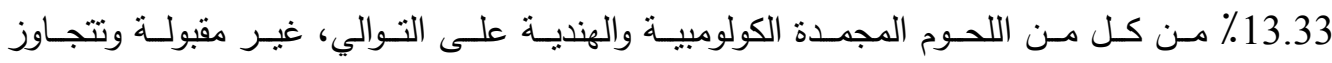
الحد الأقصى المسموح بة لعنصر الزئبق.

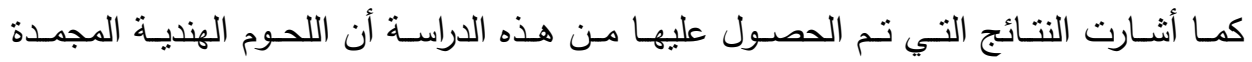

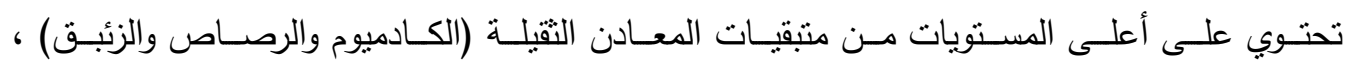
$\overline{\overline{\text { Kafrelsheikh Vet. Med. J. Vol. } 10 \text { No. } 2 \text { (2012) }}}$ يليها اللحوم الكولومبية ثم البرازيلية. 